$\theta$

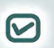

\title{
New records of social wasps in the state of Paraíba, Brazil
}

\author{
Thiago Elisei ${ }^{1 *}$, Fabio Aquino de Albuquerque ${ }^{2}$, Sergio R. Andena $^{3}$ and Celso F. Martins ${ }^{4}$
}

1 Universidade Federal da Paraíba, Programa de Pós-Graduação em Ciências Biológicas (Zoologia) / CCEN, Cidade Universitária, s/n Castelo Branco, CEP 58051-900, João Pessoa, PB, Brazil

2 Empresa Brasileira de Pesquisa Agropecuária (EMBRAPA), Rua Oswaldo Cruz, nº 1.143, Bairro Centenário, CEP 58428-095, Caixa postal 174, Campina Grande, PB, Brazil

3 Universidade Estadual de Feira de Santana, Departamento de Ciências Biológicas, Laboratória de Sistemática de Inseto, Av. Transnordestina, s/n, CEP 44036-900, Feira de Santana, BA, Brazil

4 Universidade Federal da Paraíba, Departamento de Sistemática e Ecologia / CCEN, Cidade Universitária, s/n - Castelo Branco, CEP 58051-900, João Pessoa, PB, Brazil

* Correponding author. E-mail: thiagoelisei@gmail.com

\begin{abstract}
The state of Paraíba is included in the semiarid region of Northeastern Brazil, called Caatinga, and this region is characterized by low and irregular rainfall, with xerophilous vegetation. Social wasps are an important ecological group, which has been utilized for biological control and as bioindicators of environmental quality. Few studies about the diversity of social wasps were accomplished in the Caatinga and there is no survey of social wasps in the state of Paraiba. This study used data collected from city of Sumé, through field research and analysis of previously deposited material from surveys realized by Brazilian Corporation of Agricultural Research (EMBRAPA). Two species of social wasps, Polistes simillimus and Mischocyttarus cearensis, were recorded for the first time in state of Paraiba.
\end{abstract}

Key words: Polistinae, Caatinga, Northeastern Brazil

The Caatinga is a typical biome of Northeastern Brazil, covering $844,000 \mathrm{~km}^{2}$ (IBGE 2014) (Figure 1). This biome is characterized by low irregular rainfall, and the occurrence of severe droughts is common. However, this important biome of Brazil deserves more studies regarding its biodiversity (Andena and Carpenter, 2014). Few studies about diversity of social wasps were carried out in Caatinga, and most of these studies were about floral visitors in the state of Bahia (Santos et al. 2006; Aguiar and Santos 2007; Santos et al. 2007). Nevertheless, there are no records of Polistinae species in the state of Paraíba.

Polistinae is a subfamily of Vespidae, with 29 genera and more than 900 species (Richards 1971, 1978; Carpenter et al. 1996). This group is composed by social wasps that present eusocial behavior, and may show swarm founding behavior (Jeanne 1991). According to Carpenter and Marques (2001), in Brazil there are records of social wasps from three tribes: Epiponini, Polistini and Mischocyttarini. Polistini is widely distributed in tropical and subtropical areas (Richards 1978).

Here, we report two new records of social wasps species in the state of Paraíba, collected using attractive traps and active search in two fragments of Caatinga, both surrounded by crops (cotton, corn and bean) in the municipality of Sumé $\left(07^{\circ} 40^{\prime} 18^{\prime \prime} \mathrm{S}, 036^{\circ} 52^{\prime} 54^{\prime \prime} \mathrm{W}\right.$ ) (Figure 1). Additionally, we analyzed specimens that were deposited in EMBRAPA COTTON (Brazilian Corporation of Agricultural Research, Cotton Unit).

Two species from Polistinae were found and are reported in this study (Figure 2). One of them belongs to the Polistini tribe that presents the single genus Polistes. This is a cosmopolitan genus with more than 200 species, with 38 species reported in Brazil and of them, 10 are considered endemic (Carpenter and Marques 2001). The first recorded species is Polistes simillimus Zikán, 1951, a well-studied species, in regard of its behavior

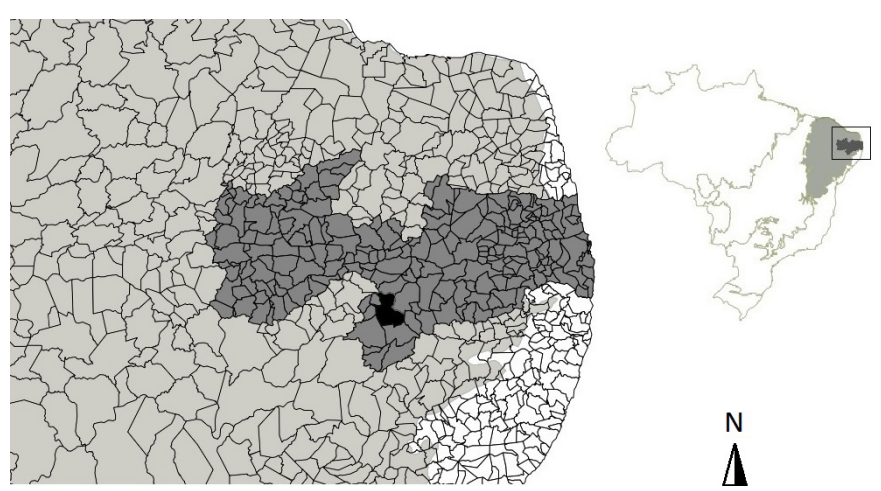

Figure 1. Map of Brazil, highlighting the biome Caatinga that covers almost $10 \%$ of the territory. Spotlight to the state of Paraiba and the municipality of Sumé, where social wasps were collected in this study. 

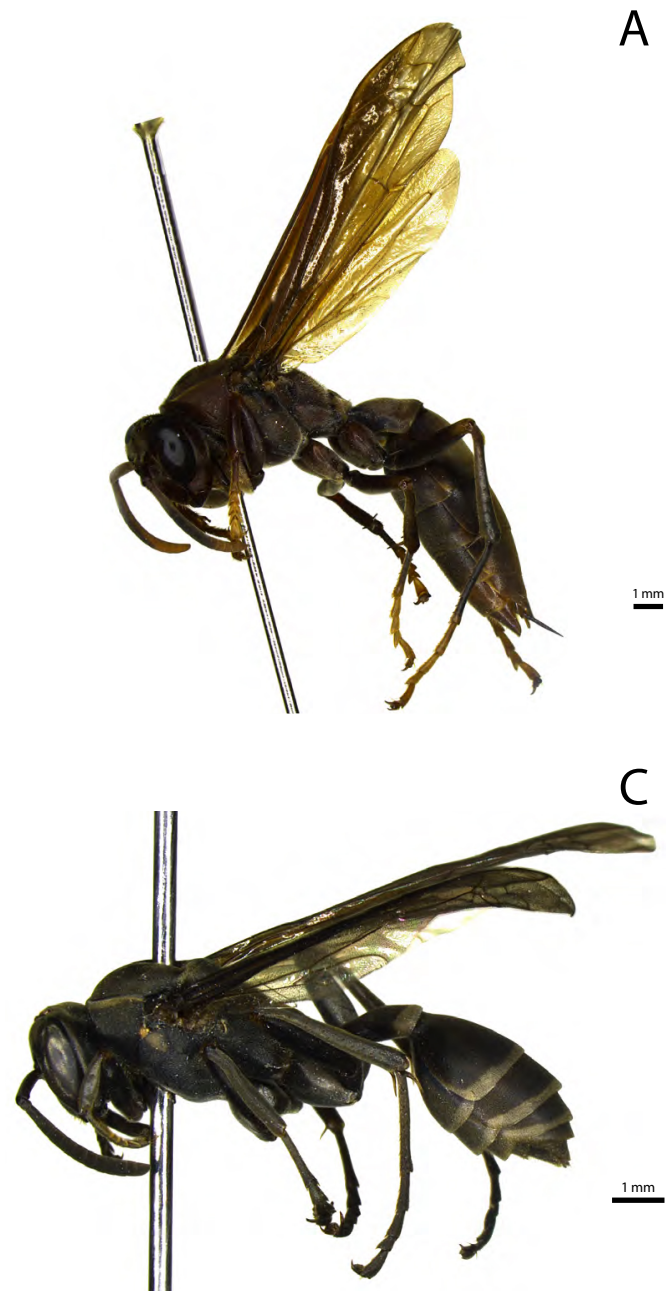

B
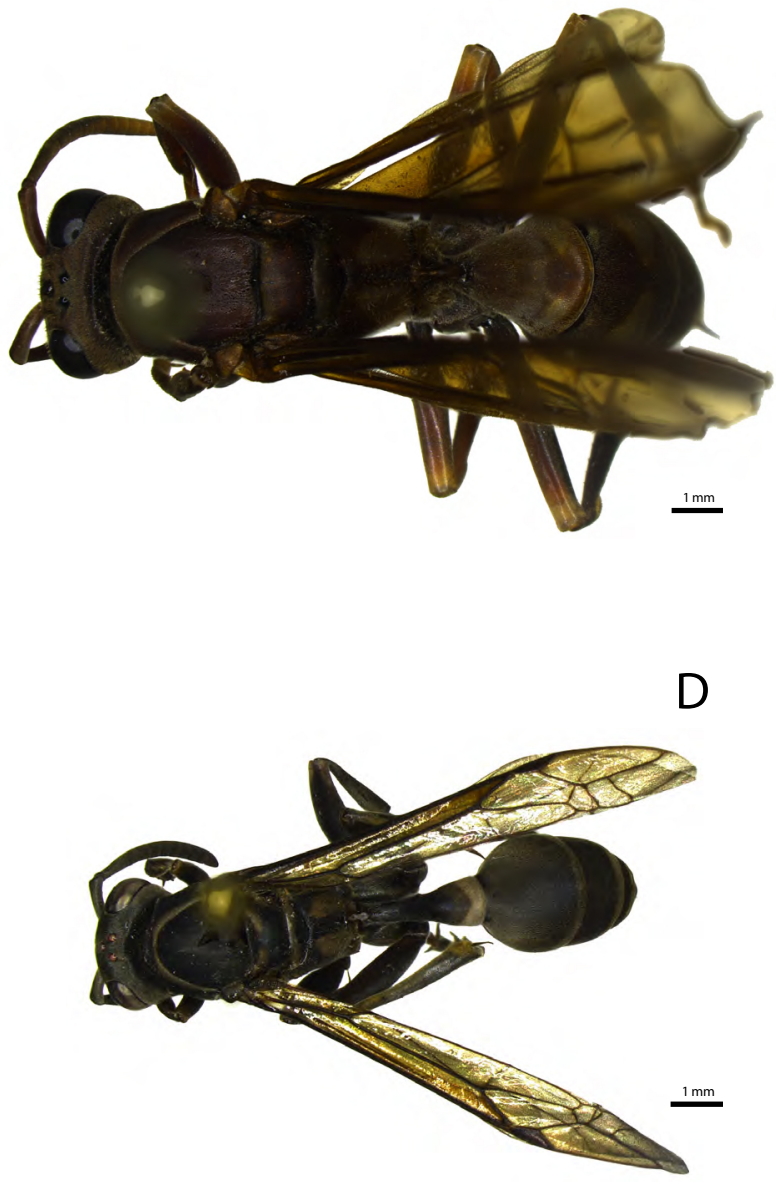

Figure 2. A: Lateral view of individual of Polistes simillimus. B: Dorsal view of individual of $P$. simillimus. C: lateral view of individual of Mischocyttarus cearensis. D: Dorsal view of individual of M. cearensis.

and natural history (Giannotti 1994; Prezoto et al. 1994; Prezoto and Machado 1999; Elisei et al. 2008).This species is very common in eastern Brazil, occurring from South Bahia to Rio Grande do Sul states, but had never been found in Paraiba state (see Andena and Carpenter 2014).

Mischocyttarini tribe also presents a single genus, Mischocyttarus that comprises 245 species, widely distributed from Argentina to the southeastern of USA (Carpenter and Marques 2001; Silveiras 2008). In Brazil, 132 species are known, including 74 considered as endemic (Richards 1978). Mischocyttarus cearensis Richards, 1945, represents the first record for this genus for Paraiba state according to Andena and Carpenter (2014).

The biodiversity of Northeastern Brazil is still largely unknown and deserves more studies as shown by the discovery of these two records. Andena and Carpenter (2014) reported only nine species of social wasps for the semiarid region of the Paraiba. Guérnard et al. (2012) exposed the importance of studies in areas with unknown diversity and high deforestation, as the Caatinga, identified by these authors as a "hotspot of discovery".
Therefore, the increase in the number of species observed can reveal that the Caatinga is not a place with low diversity of social wasps, but that it is just a poorly studied biome.

\section{ACKNOWLEDGEMENTS}

The authors thank CNPq (Conselho Nacional de Desenvolvimento Científico e Tecnológico) for financial support and Wellington Santos for preparing the photos.

\section{LITERATURE CITED}

Aguiar, C.M.L. and G.M.M. Santos. 2007. Compartilhamento de recursos florais por vespas sociais (Hymenoptera: Vespidae) e abelhas (Hymenoptera: Apoidea) em uma área de Caatinga. Neotropical Entomology 36: 836-842. doi: 10.159o/S1519566X2007000600003

Andena, S.R. and J.M. Carpenter. 2014. Checklist das espécies de Polistinae (Hymenoptera, Vespidae) do semiárido brasileiro; pp. 169-18o, in: F. Bravo and A. Calor (eds). Artrópodes do Semiárido, Biodiversidade e Conservação. Feira de Santana. Printmídia.

Carpenter, J.M., J W. Wenzel and J. Kojima. 1996. Synonymy of the genus Occipitalia Richards, 1978, with Clypearia de Saussure, 1854 (Hymenoptera: Vespidae; Polistinae, Epiponini). Journal Hymenoptera Research 5: 157-165.

Carpenter, J.M. and O.M. Marques. 2001. Contribuição ao estudo 
dos vespídeos do Brasil (Insecta, Hymenoptera, Vespoidea, Vespidade). Universidade Federal da Bahia, Série Publicações Digitais 2: $144 \mathrm{pp}$.

Elisei, T., D.L. Guimarães, C. Ribeiro Junior; A.C. Melo, D.J. Grazinoli, J.F.S.Lopes and F. Prezoto. 2008. Influence of environmental factors on the foraging activity of the paper wasp Polistes simillimus (Hymenoptera, Vespidae). Sociobiology 51: 219-130.

Giannotti, E. 1994. Notes on the biology of Polistes simillimus Zikán (Hymenoptera, Vespidae). Bioikos 8(1/2): 41-49. http:// periodicos.puc-campinas.edu.br/seer/index.php/bioikos/ article/viewFile/969/946

Guénard, B., D.M. Weiser and R.R. Dunn. 2012. Global models of ant diversity suggest regions where new discoveries are most likely are under disproportionate deforestation threat. Proceedings of the National Academy of Sciences of the United States of America 19: 7368-7373. doi: 10.1073/pnas.1113867109

Jeanne, R. L. 1991 The swarm-founding Polistinae, pp. 191-231, in: Ross, K.G. and R.W. Matthews (eds). The social biology of wasps. Ithaca: Cornell University Press $678 \mathrm{pp}$.

Prezoto, F. and V. L.L. Machado 1999. Ação de Polistes (Aphanilopterus) simillimus Zikán (Hymenoptera, Vespidae) no controle de Spodoptera frugiperda (Smith) (Lepidoptera, Noctuidae). Revista Brasileira de Zoologia 16(3): 841-851. doi: 10.1590/So10181751999000300021

Prezoto, F., E. Giannotti and V.L.L. Machado. 1994. Atividade forrageadora e material coletado pela vespa social Polistes simillimus Zikán, 1951 (Hymenoptera, Vespidae). Insecta 3: 11-19.
Richards, O.W. 1971. The biology of the social wasps (Hymenoptera: Vespidae). Biological Reviews 46: 483-528. doi: 10.1111/j.1469185X.1971.tbo1054.X

Richards, O.W. 1978. The social wasps of the Americas excluding the Vespinae. London. British Museum (Natural History). 580 pp.

Santos, G.M. de M., C.M.L. Aguiar and N. Gobbi. 2006. Characterization of the social wasp guild (Hymenoptera: Vespidae) visiting flowers in the caatinga (Itatim, Bahia, Brazil). Sociobiology 47: 483-494.

Santos, G.M.M., C.C.B. Filho, J.J. Resende, J.D. Cruz, O.M. Marques. 2007. Diversity and community structure of social wasps (Hymenoptera: Vespidae) in three ecosystems in Itaparica Island, Bahia state, Brazil. Neotropical Entomology 36: 180-185. doi: 10.1590/S1519-566X2007000200002

Silveiras, O. T. 2008. Phylogeny of wasps of the genus Mischocyttarus de Saussure (Hymenoptera, Vespidae, Polistinae). Revista Brasileira de Entomologia 52(4): 510-549. doi: 10.1590/Soo8556262008000400004

Authors' contribution statement: TE collected the data and wrote the text; CFM wrote the text; FAA wrote the text; SA wrote the text and helped in identification of wasps.

Received: July 2014

Accepted: February 2015

Editorial responsibility: Benoit Guénard 